\title{
POGLEDI IN IZKUŠNJE ERASMUSOVE MOBILNOSTI UČNEGA OSEBIA NA PEDAGOŠKI FAKULTETI UNIVERZE V MARIBORU
}

\section{POVZETEK}

Mobilnost je posledica internacionalizacije. Najbolj znana oblika internacionalizacije je mobilnost študentov. Druga pomembna oblika internacionalizacije pa je vsekakor mobilnost učnega osebja. Mobilnost učnega osebja na globalni ravni omogoča večjo mednarodno vključenost institucij, saj se domači profesorji lahko izobražujejo in sodelujejo $v$ tujini, tuji pa kot gostje predavajo domačim študentom.

Erasmusova mobilnost učnega osebja je pomemben del mednarodnega delovanja Pedagoške fakultete Univerze $v$ Mariboru (PEF UM) in njene internacionalizacije. Po mobilnosti učnega osebja se PEF uvršča v sam vrh med fakultetami Univerze v Mariboru, kar kaže na pomembnost te oblike mobilnosti in mednarodnega delovanja za samo fakulteto. Na podlagi analize vprašalnikov, ki so jih izpolnili profesorji PEF UM, smo iskali podobnosti in morebitne razlike $z$ izsledki mednarodne raziskave, ki so jo opravili Bracht in drugi raziskovalci (Bracht in drugi, 2006) o Erasmusovi mobilnosti učnega osebja.

Ključne besede: evropski programi mobilnosti, Erasmusova mobilnost učnega osebja, PEF UM

\section{THE ATTITUDES TO AND THE EXPERIENCE GAINED FROM THE ERASUMS TEACHING STAFF MOBILITY PROJECT BY THE STAFF OF THE FACULTY OF EDUCATION, UINIVERSITY OF MARIBOR - ABSTRACT}

Mobility is a consequence of internationalization. The best known form of internationalization is student mobility. Second in importance for internationalization is the mobility of teaching staff, as it fosters international cooperation of institutions at a global level: lecturers of a faculty can receive education abroad and foreign professors can give lectures to domestic students. The Erasmus teaching staff mobility project is an important part of the international activities of the Faculty of Education, University of Maribor (PEF UM) and its internationalization. The teaching staff mobility of the Faculty of Education is the highest within the University of Maribor, which shows the importance of this type of activity. We analyzed the questionnaire responses provided by the mobile teaching staff of PEF UM and compared them with the findings of the international research study by Bracht and others (Brachts in drugi 2006), who investigated the Erasmus teaching staff mobility.

Keywords: European mobility programmes, Erasmus teaching staff mobility, Faculty of Education, University of Maribor (PEF UM)

UDK: 378

\section{UVOD}

Mobilnost je posledica internacionalizacije. Visokošolske institucije so del te internacionalizacije kot posledica svetovnega materialnega in intelektualnega razvoja. Tako je veliko univerz vključenih v konkurenčni boj na »izobraževalnem trgu«. Da lahko v tem boju uspešno konkurirajo in $\mathrm{v}$ nekaterih primerih vsaj preživijo oz. obstanejo, morajo biti internacionalizirane (Valius, 2006). Res je, da je mobilnost študentov (študenti, ki študirajo $\mathrm{v}$ tujini in ne doma oz. ki gredo za določeno obdobje na izmenjavo $v$ tujino) najbolj zna- 
na oblika internacionalizacije. Druga najpomembnejša oblika internacionalizacije pa je vsekakor mobilnost učnega osebja (Van Damme, 2001). Mobilnost učnega osebja na globalni ravni omogoča večjo mednarodno vključenost institucij, saj se domači profesorji lahko izobražujejo in sodelujejo pri projektih $\mathrm{v}$ tujini, tuji pa kot gostje predavajo domačim študentom. Tako institucije svoje študente pripravljajo za prihodnost, ko jih bodo primerjali ne samo s študenti institucij matične države, ampak tudi s študenti institucij v tujini (Valius, 2006).

Tradicionalna mednarodna mobilnost profesorjev je usmerjena v raziskovalno delo in štipendiranje za slednje, izobraževanje in poučevanje pa sta postala vzroka za mobilnost šele v zadnjih letih (Van Damme, 2001). Welch je $\mathrm{v}$ raziskavi The Internationalisation of Academic Staff ugotovil, da so akademiki s področja poslovnih ved predvidoma manj mobilni, kadar je namen mobilnosti pridobitev višjega akademskega naziva. Podobno so bili ocenjeni tudi akademiki s področja tehničnih, zdravstvenih in pedagoških ved. Znanstvene discipline, ki so bile $\mathrm{v}$ omenjeni raziskavi visoko ocenjene (kadar je namen mobilnosti pridobitev višjega akademskega naziva), so bile računalništvo in fizika ter družboslovje. Vzorec, ki ga je Welch uporabil za svojo raziskavo, je vključeval 20 tisoč predstavnikov akademskega osebja na visokošolskih institucijah iz 14 držav (Welch, 1997).

Tudi EU se je odločila, da bo mobilnost intenzivneje spodbujala. Mobilnost profesorjev in študentov so tako začeli bolj poudarjati v 50. letih, ko je bila namenjena zgolj visokokvalificiranim strokovnjakom. Leta 1969 je Evropski svet v Strasbourgu sprejel sklep, da je mobilnost v visokošolskih krogih treba povečati oziroma jo spodbujati. Od takrat dalje se je v okviru EU zvrstilo veliko različnih programov mobilnosti, od Comett do Socrates in Erasmus ter drugih (Agbossou, Carel, Caro, 2008).

Evropska komisija je leta 2004 sprejela predlog programov EU s področja vseživljenjskega učenja, ki naj bi nadomestili dotedanje programe (Socrates, Leonardo da Vinci in E-učenje) (Nekrep, Vihar, 2007). Nastal je program Vseživljenjsko učenje za obdobje 2007-2013, ki je osrednji program EU na področju izobraževanja in usposabljanja in je bil ustanovljen s sklepom Evropskega parlamenta in Sveta. Njegov namen je prispevati $\mathrm{k}$ razvoju družbe z vrhunskim znanjem, trajnostnim gospodarskim razvojem, večjo socialno kohezijo, več in bolj kakovostnimi delovnimi mesti ter zagotavljanjem varstva okolja. Program Vseživljenjsko učenje podpira sodelovanje in mobilnost med sistemi izobraževanja in usposabljanja v Evropi s ciljem postati svetovna referenca za kakovost. Razdeljen je na štiri podprograme, ki so namenjeni različnim ciljnim skupinam (CMEPIUS, 2007 a). Ti podprogrami pokrivajo posebna področja izobraževanja oziroma usposabljanja (CMEPIUS, 2007 b), in sicer kot sledi:

- podprogram COMENIUS je namenjen področju poučevanja in učenja vseh udeležencev predšolskega, osnovnošolskega vse do konca višje stopnje srednješolskega izobraževanja in podpira mednarodno sodelovanje organizacij, ki izvajajo takšna izobraževanja;

- podprogram ERASMUS pokriva področje poučevanja in učenja vseh udeležencev formalnega visokošolskega izobraževanja ter poklicnega izobraževanja in usposabljanja na terciarni ravni (ne glede na trajanje izobraževanja ali stopnjo kvalifikacije). Vključuje tudi doktorski študij in mednarodno sodelovanje organizacij, ki izvajajo oziroma omogočajo takšno izobraževanje in usposabljanje; 
- podprogram LEONARDO DA VINCI zadovoljuje potrebe, povezane $s$ poučevanjem in učenjem vseh udeležencev poklicnega izobraževanja in usposabljanja (ne vključuje terciarne ravni). Vključuje tudi mednarodno sodelovanje organizacij, ki izvajajo ali omogočajo takšno izobraževanje in usposabljanje;

- podprogram GRUNDTVIG je namenjen področju poučevanja in učenja udeležencev vseh oblik izobraževanja odraslih in mednarodnemu sodelovanju organizacij, ki izvajajo oziroma omogočajo to izobraževanje.

\section{Mobilnost v visokem šolstvu je treba spodbujati in okrepiti.}

Cilji podprograma Erasmus so spodbujati mednarodno mobilnost posameznikov in povečati obseg različnih oblik sodelovanja med organizacijami ter dvigniti kakovost terciarnega izobraževanja $\mathrm{v}$ Evropi. Omenjeni podprogram ni namenjen zgolj študentom in njihovi mobilnosti za študij ali opravljanje delovne prakse $\mathrm{v}$ tujini, ampak podpira tudi sodelovanje visokošolskih institucij po Evropi ter spodbuja profesorje in strokovnjake, da poučujejo in se tudi sami izobražujejo v tujini. Prav tako Erasmus omogoča mobilnost zaposlenih na visokošolskih institucijah, ki se lahko dodatno izobražujejo v okviru različnih delavnic ali mednarodnih srečanj (European Commission, 2010 a).

Erasmusova mobilnost učnega osebja omogoča profesorjem in vabljenim gostom oziroma strokovnjakom iz podjetij, da v obdobju od enega dne do maksimalno šest tednov izvajajo pedagoške obveznosti na partnerski visokošolski instituciji v tujini, pri čemer morajo opraviti najmanj pet predavateljskih ur. Cilji Erasmusove mobilnosti učnega osebja so (European Commission, 2010 b):
- $\quad$ spodbujati visokošolske zavode k širjenju obsega in bogatenju vsebine predavanj, ki jih ponujajo;

- omogočiti študentom, ki ne morejo sodelovati v shemi mobilnosti, da pridobijo znanja in izkušnje, ki jim jih ponuja akademsko osebje iz visokošolskih zavodov iz drugih evropskih držav in osebje, ki je povabljeno iz podjetij, prav tako iz drugih evropskih držav;

- $\quad$ spodbujati izmenjavo strokovnega znanja in izkušenj o pedagoških metodah;

- ustvarjati povezave med visokošolskimi zavodi in med podjetji;

- $\quad$ spodbujati študente in osebje na visokošolskih institucijah $\mathrm{k}$ mobilnosti in jim zagotavljati pomoč $\mathrm{v}$ pripravljalni fazi mobilnosti.

Učno osebje oz. profesorji imajo v okviru Erasmusove mobilnosti pomembno vlogo. Odgovorni so za vzpostavitev stikov in oblikovanje partnerstev s tujino. Podpis sporazumov je velikokrat posledica prav njihovih predhodnih poznanstev z različnih konferenc ali sodelovanja v mednarodnih projektih. Velikokrat Erasmusov mobilni profesor nastopa tudi v vlogi koordinatorja postopka za Erasmusovo mobilnost študentov. Ta vloga združuje svetovanje študentom in pomoč pri izbiri ustrezne institucije v tujini, kamor bodo odšli, pregled študijskih aktivnosti v tujini $v$ času izmenjave in njihove kompatibilnosti s študijskimi obveznostmi na domači instituciji, tako da je zadoščeno evropskemu prenosnemu kreditnemu sistemu ECTS $^{1}$ (Agbossou, Carel, Caro, 2008).

\section{Izkušnje Erasmusove mobilnosti med učnim osebjem na Pedagoški fakulteti Univerze v Mariboru}

Erasmusova mobilnost učnega osebja je bila na evropski ravni že večkrat raziskovana in proučevana. Ena od raziskav - avtorja sta 
Kreitz in Teichler ${ }^{2}$ - je proučevala mobilnost profesorjev v študijskem letu 1990/91 in je pokazala, da je bilo za profesorje kot posledica mobilnosti izredno pomembno izboljšanje mednarodnega in medkulturnega razumevanja, spoznavanje novih učnih metod, ki jih na domači instituciji niso uporabljali, pridobitev novih kontaktov za raziskovalno delo ter izboljšanje znanja tujega jezika. Druga raziskava je bila na podlagi Erasmusove mobilnosti profesorjev opravljena $\mathrm{v}$ študijskem letu 1998/99, avtorja pa sta Maiworm in Teichler. ${ }^{3}$ Rezultati te raziskave so bili podobni prvi, z izjemo tega, da za profesorje kot posledica mobilnosti ni bilo več tako relevantno izboljšanje znanja tujega jezika (Bracht in drugi, 2006). Zadnja raziskava, ki se nanaša na mobilnost v študijskem letu 2000/01 in so jo opravili Bracht in drugi, pa kaže, da je več kot 58 odstotkov anketiranih profesorjev prepoznavalo pozitivne vplive podprograma Erasmus za njihov profesionalni razvoj. Čeprav je poudarek Erasmusa na poučevanju in ne na raziskovalnem delu, je izjemno velik tudi vpliv mobilnosti na raziskovalne dejavnosti: 65 odstotkov vprašanih je poročalo o splošnem izboljšanju njihovih stikov s področja raziskovanja, 60 odstotkov jih je poročalo o širjenju in izboljšanju njihovega akademskega znanja v času mobilnosti, 40 odstotkov vprašanih pa je poudarilo pomen razvoja in implementacije novih učnih metod (European Commission, 2008).

Na podlagi vprašanj te zadnje raziskave smo pripravili anketni vprašalnik za profesorje Pedagoške fakultete Univerze $\mathrm{v}$ Mariboru (PEF UM), ki so svojo mobilnost učnega osebja izkoristili v študijskem letu 2009/10, namen naše raziskave pa je bil primerjati njihove izkušnje mobilnosti in poglede nanjo z zadnjimi raziskavami s tega področja, opravljenimi v Evropi. Na podlagi analize vprašalnikov profesorjev PEF UM smo iskali podobnosti in morebi- the razlike $\mathrm{z}$ izsledki mednarodne raziskave ter pridobljene rezultate tudi komentirali.

V študijskem letu 2009/10 je mobilnost učnega osebja izkoristilo 18 profesorjev PEF UM, na ravni Univerze v Mariboru pa 95 predstavnikov učnega osebja (Univerza v Mariboru, 2011), medtem ko je bilo na celotni evropski ravni $\mathrm{v}$ tem študijskem letu izvedenih skupaj 29.031 Erasmusovih mobilnosti učnega osebja. Povprečno trajanje mobilnosti je bilo pet do šest dni, 41 odstotkov udeležencev mobilnosti je bilo žensk (European Commission, 2011).

Anketni vprašalnik smo poslali vsem 18 profesorjem, ki so v študijskem letu 2009/10 izkoristili Erasmusovo mobilnost učnega osebja, nazaj pa smo jih dobili 13, kar pomeni 72-odstotno odzivnost. Na podlagi izpolnjenih vprašalnikov smo ugotovili, da je bilo 38 odstotkov udeležencev Erasmusove mobilnosti učnega osebja žensk, kar je primerljivo s prej omenjenimi vseevropskimi podatki. Nadalje je bilo 54 odstotkov anketiranih starih med 45 in 54 let, 23 odstotkov anketiranih je bilo starejših od 55 let, 15 odstotkov je bilo starih med 35 in 44 let ter osem odstotkov med 25 in 35 let. Pri največjem deležu anketiranih (38 odstotkov) je Erasmusova mobilnost učnega osebja trajala sedem dni ali več, pri 31 odstotkih anketiranih tri do štiri dni, enak odstotek pa jih je bilo mobilnih pet do šest dni. Če primerjamo te podatke s prej omenjenimi vseevropskimi, vidimo, da je mobilnost profesorjev na PEF UM v študijskem letu 2009/10 v povprečju trajala dlje. Izmed anketiranih udeležencev Erasmusove mobilnosti na PEF UM je bilo 61 odstotkov rednih profesorjev, osem odstotkov izrednih profesorjev, 23 odstotkov docentov in osem odstotkov asistentov.

Najpogostejši vzroki oz. povodi za odločitev za Erasmusovo mobilnost učnega osebja, ki so bili navedeni $\mathrm{v}$ raziskavi Brachta in drugih 
raziskovalcev (Bracht in drugi, 2006), so predhodni kontakti oz. sodelovanje domače institucije in institucije gostiteljice na področju izobraževalnih programov, in to kar pri 81 odstotkih vprašanih, ter dobri, že utrjeni odnosi oz. sodelovanje $\mathrm{z}$ zaposlenimi na instituciji gostiteljici v 85 odstotkih. Tudi izsledki ankete učnega osebja PEF UM so podobni: 77 odstotkov vprašanih je kot povod za mobilnost navedlo sodelovanje domače institucije in institucije gostiteljice, 92 odstotkov vprašanih pa je kot dodaten povod za mobilnost navedlo še dobre, že utrjene kontakte z zaposlenimi na instituciji gostiteljici. Na podlagi raziskave Brachta in drugih (2006) je za profesorje iz Srednje in Vzhodne Evrope Erasmusova mobilnost zanimiva $\mathrm{z}$ več vidikov, ki vplivajo na njihovo odločitev za mobilnost, kot za profesorje držav Zahodne Evrope. Za predavatelje iz Srednje in Vzhodne Evrope niso pomembni zgolj predhodni kontakti, ampak tudi inovativne strategije in tehnike poučevanja na tuji instituciji ter visok akademski standard tuje institucije (kot enega izmed povodov za mobilnost je to navedlo 77 odstotkov anketiranih predavateljev iz Srednje in Vzhodne Evrope in le 52 odstotkov anketiranih predavateljev iz držav Zahodne Evrope). Na podlagi analize anketnih vprašalnikov profesorjev PEF UM lahko ugotovimo, da je ta vidik med drugim vplival na odločitev za mobilnost pri 85 odstotkih vprašanih, kar je primerljivo z izsledki za anketirane predavatelje iz Srednje in Vzhodne Evrope.
Na podlagi evropske raziskave (prav tam) je 12 odstotkom vprašanih mobilnost koristila oz. jim je omogočila dosego višjega akademskega naziva (v državah Zahodne Evrope le sedem odstotkov, v državah Srednje in Vzhodne Evrope pa 30 odstotkov). $\mathrm{V}$ primeru PEF UM je ta delež primerljiv z državami Zahodne Evrope, saj znaša zgolj osem odstotkov. Torej lahko sklepamo, da dosega višjega akademskega naziva ni primarna motivacija za Erasmusovo mobilnost učnega osebja.

Pomemben vidik pri Erasmusovi mobilnosti je tudi izboljšanje mednarodnega oz. medkulturnega razumevanja. $\mathrm{V}$ raziskavi na evropski ravni (prav tam) je ta vidik navedlo 92 odstotkov anketiranih. Med učnim osebjem PEF UM pa je 85 odstotkov vprašanih menilo, da je Erasmusova mobilnost učnega osebja pripomogla $\mathrm{k}$ izboljšanju njihovega mednarodnega oz. medkulturnega razumevanja, kar pomeni, da je podatek primerljiv z evropskim. Večji delež vprašanih predavateljev PEF UM (77 odstotkov), ki so v študijskem letu 2009/10 izkoristili Erasmusovo mobilnost, je ocenilo, da je mobilnost okrepila kontakte na področju njihovega raziskovalnega dela. Enak delež vprašanih je tudi navedel, da je njihova mobilnost spodbudila vzpostavitev novega sodelovanja in različnih skupnih projektov z institucijo gostiteljico. Izsledki evropske raziskave za omenjeni dve področji znašajo le 65 odstotkov $\mathrm{v}$ prvem primeru, ki se nanaša na

V raziskavi Brachta in drugih raziskovalcev (Bracht in drugi, 2006) so pozornost namenili tudi oceni vpliva Erasmusove mobilnosti učnega osebja na profesionalni razvoj udeleženca mobilnosti. Ugotovili so, da je 58 odstotkov vprašanih ocenilo, da je mobilnost imela pozitiven vpliv na njihov profesionalni razvoj. V analizi naše ankete pa smo ugotovili, da je ta delež še večji: da je mobilnost pozitivno vplivala na njihov profesionalni razvoj, je ocenilo kar 92 odstotkov anketiranih. Ta delež dokazuje, kako pomembna je za predavatelje PEF UM Erasmusova mobilnost učnega osebja. Njeno pomembnost potrjuje tudi primerjava števila mobilnih profesorjev na ravni Univerze v Mariboru, kjer PEF UM v študijskem letu 2009/10 prednjači skupaj s FERI UM ${ }^{4}$ z 18 mobilnostmi učnega osebja. Mobilnost na preostalih fakultetah Univerze v Mariboru se v omenjenem študijskem letu giblje med enim in 10 mobilnimi učitelji (Univerza v Mariboru, 2011). 
raziskovalno delo, in 67 odstotkov v drugem primeru, ki se nanaša na nova sodelovanja in skupne projekte (prav tam). Izsledki raziskave, narejene na PEF UM, so veliko bolj primerljivi z izsledki evropske raziskave (prav tam) za regijo Srednja in Vzhodna Evropa, saj je 80 odstotkov anketiranih predavateljev slednje regije navedlo, da jim je Erasmusova mobilnost omogočila krepitev stikov na področju raziskovalnega dela. Za predavatelje iz držav Srednje in Vzhodne Evrope pomeni Erasmusova mobilnost močno spodbudo za njihovo raziskovalno delo in projektno sodelovanje, saj je zanje prav to namen mobilnosti (iskanje novih stikov, izboljšanje obstoječih stikov in posledično razvijanje raziskovalnega dela in skupnih projektov). V državah Zahodne Evrope pa mobilnost sicer tudi vpliva na opisani vidik, a ta vpliv ni tako velik, medtem ko je zanje pomemben tudi prenos pedagoških znanj in kompetenc ter inovativnih strategij in tehnik poučevanja.

Mobilno učno osebje, vključeno $\mathrm{v}$ raziskavo Brachta in drugih raziskovalcev, je prepričano, da je Erasmusova mobilnost imela pozitiven vpliv na njihove domače visokošolske institucije. V državah Srednje in Vzhodne Evrope je ta pozitivni vpliv navedlo 67 odstotkov vprašanih, v državah Zahodne Evrope pa 47 odstotkov. Na PEF UM je 73 odstotkov anketiranih navedlo, da je bil vpliv opravljene mobilnosti opazen in pozitiven za njihovo domačo institucijo, torej za PEF UM.

V Tabeli 1 vidimo primerjavo analize Brachta in drugih (2006), razdeljene na države Zahodne Evrope, države Srednje in Vzhodne Evrope ter s skupnimi podatki za Evropo, z analizo, opravljeno na PEF UM, in sicer po posameznih področjih vpliva Erasmusove mobilnosti učnega osebja na domači instituciji po mnenju anketirancev. Rezultati analiz so velikokrat medsebojno primerljivi, zelo pogosto so rezul- tati analize mobilnosti učnega osebja PEF UM bliže rezultatom, značilnim za države Srednje in Vzhodne Evrope, kar je smiselno, saj je Slovenija, kjer deluje PEF UM, del omenjene regije. Mentaliteta ljudi v tej regiji je podobna, kakor tudi šolski sistem in način izobraževanja, ki teži po nenehnem izboljševanju in napredku ter kaže željo po doseganju standardov in načinov šolanja, značilnih za zahodnoevropske države. Večje odstopanje, ki ga opazimo, je na področju vpliva Erasmusove mobilnosti učnega osebja na izboljšanje svetovanja bodočim mobilnim študentom na domači instituciji, kar je 92 odstotkov vprašanih predavateljev na PEF UM navedlo kot pomembno in relevantno za njihovo institucijo po koncu njihove mobilnosti, v primerjavi s 63 odstotki na evropski ravni. To odraža dejstvo, da se predavatelji PEF UM pomembno zanimajo za svoje študente in jim na podlagi lastnih izkušenj v času mobilnosti želijo čim bolj predstaviti delovanje tuje institucije in njene značilnosti, kar študentu pomaga pri odločanju glede mobilnosti. To pa je tudi eden izmed ciljev omenjenega programa.

Drugo večje odstopanje od evropskih podatkov zaznamo na področju uporabe tuje literature na domači instituciji po izteku mobilnosti učnega osebja. To je najverjetneje povezano s prej obravnavanim dejstvom, da se z mobilnostjo krepijo stiki udeležencev mobilnosti na področju njihovega raziskovalnega dela in sodelovanja pri različnih projektih $\mathrm{z}$ institucijo gostiteljico, in to velikokrat rezultira v priporočilu različne literature med kolegi, kar nato mobilni predavatelji ponudijo in predstavijo na domači instituciji. V primeru PEF UM ta delež znaša 77 odstotkov, na ravni držav Srednje in Vzhodne Evrope 64 odstotkov, na skupni evropski ravni pa le 39 odstotkov.

Zadnje večje odstopanje lahko opazimo v kategoriji priprave skupnih študijskih programov $^{5}$ (duble degree programs). Vpliv 
Tabela 1: Analiza vpliva Erasmusove mobilnosti učnega osebja na domačo institucijo po področjih po mnenju Erasmusovih mobilnih profesorjev (podatki podani v odstotkih)

\begin{tabular}{|c|c|c|c|c|}
\hline Področje vpliva & $\begin{array}{l}\text { Države } \\
\text { Zahodne } \\
\text { Evrope }^{1}\end{array}$ & $\begin{array}{l}\text { Države Srednje } \\
\text { in Vzhodne } \\
\text { Evrope }^{2}\end{array}$ & $\begin{array}{l}\text { SKUPAJ } \\
\text { (evropske } \\
\text { države) }^{3}\end{array}$ & PEF UM ${ }^{4}$ \\
\hline $\begin{array}{l}\text { Boljše svetovanje bodočim mobilnim } \\
\text { študentom domače institucije }\end{array}$ & 62 & 69 & 63 & 92 \\
\hline $\begin{array}{l}\text { Posredovanje znanja o drugih } \\
\text { državah, Evropi itd. }\end{array}$ & 58 & 57 & 58 & 54 \\
\hline $\begin{array}{l}\text { Koordinacija izobraževalnih } \\
\text { programov domače in partnerske } \\
\text { institucije }\end{array}$ & 47 & 46 & 47 & 46 \\
\hline $\begin{array}{l}\text { Možnost poučevanja vašega } \\
\text { lastnega predmeta v tujem jeziku }\end{array}$ & 39 & 64 & 44 & 54 \\
\hline $\begin{array}{l}\text { Razvoj novih kompetenc in vsebin za } \\
\text { študijske programe }\end{array}$ & 35 & 64 & 41 & 62 \\
\hline Uporaba literature $v$ tujem jeziku & 33 & 64 & 39 & 77 \\
\hline $\begin{array}{l}\text { Ponuditi znanje o mednarodnih } \\
\text { odnosih in organizacijah }\end{array}$ & 38 & 39 & 38 & 38 \\
\hline $\begin{array}{l}\text { Podajanje predlogov teoretičnih } \\
\text { diskusii, s katerimi ste se seznanili v } \\
\text { državi gostiteljici }\end{array}$ & 37 & 43 & 38 & 54 \\
\hline $\begin{array}{l}\text { Priprava skupnih študiijkih } \\
\text { programov (duble degree programs) }\end{array}$ & 36 & 28 & 34 & 23 \\
\hline Razvoj novih metod poučevanja & 26 & 55 & 32 & 38 \\
\hline $\begin{array}{l}\text { Integracija tečaja tujega jezika } \\
\text { države gostitelijice v kurikulum }\end{array}$ & 25 & 42 & 29 & 23 \\
\hline
\end{tabular}

Vir: prirejeno po Bracht in drugi (2006: 134) ter lastni analizi.

Opomba: 1, 2 in 3 povzeto po Bracht in drugi, 2006.

4 lastni podatki, pridobljeni z analizo, opravljeno na PEF UM.

mobilnosti učnega osebja na tem področju na domačo institucijo po podatkih za PEF UM znaša le 23 odstotkov, za države Srednje in Vzhodne Evrope 28 odstotkov in za države Zahodne Evrope 36 odstotkov. Tako majhen delež na PEF UM je posledica strožje slovenske zakonodaje, ki za pripravo omenjenih programov zahteva obilo dokazil, potrdil in postavlja stroga administrativna določila. ${ }^{6}$

\section{SKLEP}

Podprogram Erasmus ni namenjen zgolj študentom in njihovi mobilnosti, ampak podpira tudi sodelovanje visokošolskih institucij po Evropi ter spodbuja profesorje in strokovnjake, da poučujejo oz. se tudi sami izobražujejo $\mathrm{v}$ tujini ter tako pripomorejo $\mathrm{k}$ večji internacionalizaciji domače institucije. Omenjeni pod- 
program je pomemben del mednarodnega delovanja PEF UM in njene internacionalizacije, tako na ravni mobilnosti študentov kot tudi učnega osebja. Po mobilnosti učnega osebja se PEF UM uvršča v sam vrh med fakultetami Univerze v Mariboru, kar kaže na pomembnost te oblike mobilnosti in mednarodnega delovanja za samo fakulteto. Prav zato smo se lotili podrobnejše raziskave in zbrali podatke o Erasmusovi mobilnosti učnega na PEF UM v študijskem letu 2009/10.

Cilji Erasmusove mobilnosti učnega osebja (European Commission, 2010 b) so tudi s to mobilnostjo na PEF UM doseženi, kar je potrdila raziskava med mobilnimi predavatelji na PEF UM:

- $\quad$ Spodbujati visokošolske zavode k širjenju obsega in bogatenju vsebine predavanj, ki jih ponujajo - Predavatelji PEF UM z raziskovalnim delom in sodelovanjem ter različnimi skupnimi projekti z institucijo gostiteljico, ki se razvijejo kot posledica mobilnosti, bogatijo obseg in vsebino svojih predavanj ter tako tudi študentom omogočajo vpogled $\mathrm{v}$ nova znanja, odkritja in aktualne vsebine.

- Omogočiti študentom, ki ne morejo sodelovati v shemi mobilnosti, da pridobijo znanja in izkušnje, ki jim jih ponuja akademsko osebje iz visokošolskih zavodov iz drugih evropskih držav in osebje, ki je povabljeno iz podjetij, prav tako iz drugih evropskih držav - Prenos znanj, ki jih predavatelji pridobijo s svojo lastno mobilnostjo in nato prenesejo na študente, smo pravkar omenili. Ne smemo pa pozabiti na mobilnost tujih predavateljev, ki pridejo na izmenjavo na PEF UM in tako študentom te institucije posredujejo svoja znanja ter jim hkrati predstavijo tudi svojo državo. Omenjena oblika mobilnosti tokrat ni bila vključe- na $\mathrm{v}$ raziskavo, zato $\mathrm{z}$ natančnimi podatki oz. številu takšnih oblik mobilnosti ne razpolagamo.

- Spodbujati izmenjavo strokovnega znanja in izkušenj o pedagoških metodah - Kot je bilo že navedeno, je za predavatelje PEF UM zelo pomembno, da je njihova mobilnost učnega osebja spodbudila vzpostavitev novega sodelovanja in različne skupne projekte $\mathrm{z}$ institucijo gostiteljico, predvsem s področja pedagoškega dela, in to kar pri 77 odstotkih vprašanih.

- Ustvarjati povezave med visokošolskimi zavodi in s podjetji - Zaradi posebnosti PEF UM, ki je specializirana z primarno/elementarno izobraževanje, povezava z gospodarstvom in podjetji ni možna. Povezava z visokošolskimi zavodi pa se kaže $\mathrm{v}$ pogosti mobilnosti predavateljev PEF UM oz. rezultira v sodelovanju med institucijami po končani mobilnosti (skupno raziskovalno delo, skupni projekti in druga sodelovanja med institucijami).

- $\quad$ Spodbujati študente in osebje na visokošolskih institucijah $k$ mobilnosti in jim zagotavljati pomoč v pripravljalni fazi mobilnosti - Kot smo omenili, je 92 odstotkov vprašanih predavateljev na PEF UM kot pomembno in relevantno za njihovo institucijo po koncu njihove mobilnosti navedlo izboljšanje na področju svetovanja bodočim mobilnim študentom domače institucije.

\section{LITERATURA IN VIRI}

Agbossou, I., Carel, S., Caro, P. (2008). European Exchange with Erasmus: Increasing University Teachers' Mobility to Promote Students' Exchange. Céreq, 79: 1-4.

Bracht, O., Engel, C., Janson, K., Over, A., Schomburg, H., Teichler, U. (2006). The professional Value of ERASMUS Mobility. Kassel: INCHER. 
Program Vseživljenjsko učenje (2007). Center RS za mobilnost in evropske programe izobraževanja in usposabljanja - CMEPIUS (a). Dostopno na: http://www.cmepius.si/vzu/vse-o-vzu/uvod-v-program-vzu.aspx (pridobljeno 28. 11. 2011).

Podprogrami (2007). Center RS za mobilnost in evropske programe izobraževanja in usposabljanja - CMEPIUS (b). Dostopno na: http://www.cmepius.si/vzu/vse-o-vzu/o-podprogramih.aspx (pridobljeno 28. 11. 2011).

The Impact of ERASMUS on European Higher Education: Quality, Openness and Internationalisation (2008). European Commission: Directorate-General for Education and Culture.

The Erasmus Programme - studying in Europe and more (2010). European Commission: Education and Training (a). Dostopno na: http://ec.europa.eu/ education/lifelong-learning-programme/doc 80 en.htm (pridobljeno 28. 11. 2011).

Erasmus Staff Mobility - Teaching Assignments by High Education Institutions Teaching Staff and by Invited Staff from Enterprises (2010). European Commission: Education and Training (b). Dostopno na: http://ec.europa.eu/education/erasmus/ doc1067_en.htm (pridobljeno 28. 11. 2011).

Erasmus - Facts, Figures \& Trends (The European Union support for student and staff exchange and university cooperation in 2009/2010) (2011). Luxembourg: European Commission: Education and Culture DG, Publication Office of the European Union.

Nekrep, A., Vihar, N. (2007). Značilnost Erasmus mobilnosti študentov in učiteljev na Univerzi v Mariboru. V: Vovk Korže, A. (ur.), Priložnosti v izobraževanju z bolonjsko reformo $v$ Sloveniji. Maribor.

Merila za kreditno vrednotenje študijskih programov po ECTS (2004 a). Ljubljana: Svet Republike Slovenije za visoko šolstvo.

Merila za akreditacijo visokošolskih zavodov in študijskih programov (2004 b). Ljubljana: Svet Republike Slovenije za visoko šolstvo.

Skupni študijski programi na UL (2011). Univerza v Ljubljani. Dostopno na: http://www.uni-lj.si/studij_na_univerzi/skupni_studijski_programi_na_ ul.aspx (pridobljeno 6. 12. 2011).
Mobilnost na Univerzi v Mariboru v obdobju 1999 2011 v luči statistike (2011). Univerza v Mariboru. Oddelek za mednarodne, raziskovalne in študentske zadeve. Služba za mednarodno in meduniverzitetno sodelovanje.

Valius, V. A., Valius, D. (2006). The Internationalisation of Higher Education: a Challenge for Universities. Global Journal of Engineering Education, 2: 221-228.

Van Damme, D. (2001). Quality issues in the internationalisation of higher education. Higher Education, 4: 415-441.

Welch, A. R. (1997). The Peripatetic Professor: The Internationalisation of the Academic Profession. Higher Education, 3: 323-345.

1. ECTS je sistem za nabiranje in prenos kreditnih točk. Izboljšuje preglednost in primerljivost sistemov in študijskih programov ter omogoča mobilnost študentov in medsebojno priznavanje opravljenih študijskih obveznosti. Uporablja se za nabiranje kreditnih točk, potrebnih za končanje študijskega programa, pa tudi za prenos kreditnih točk $z$ enega študijskega programa $\mathrm{v}$ drugega, in sicer med visokošolskimi zavodi $\mathrm{v}$ Republiki Sloveniji ter med visokošolskimi zavodi iz Republike Slovenije in tujine (Svet Republike Slovenije za visoko šolstvo, 2004 a: 2. člen).

2. Kreitz, R., in Teichler, U. (1997). Erasmus Teaching Staff Mobility: The 1990/91 Teacher's View. Kassel: Wissenschaftliches Zentrum für Berufs- und Hochschulforschung der Universität Gesamthochschule Kassel.

3. Maiworm, F., in Teichler, U. (2002). »The Academics' Views and Experiences«, objavljeno v publikaciji ERASMUS in the SOCRATES Programme: Findings of an Evaluation Study. Bonn: Lemmens.

4. FERI UM - Fakulteta za elektrotehniko, računalništvo in informatiko Univerze v Mariboru.

5. Skupni študijski programi so študijski programi za pridobitev izobrazbe na 1., 2. ali 3. stopnji, ki jih skupaj izvajata dve ali več univerz oz. samostojnih visokošolskih zavodov. Diplomanti, ki opravijo vse obveznosti po teh programih, praviloma pridobijo eno skupno diplomo, ki jo izdajo udeležene univerze (Univerza v Ljubljani, 2011).

6. Več o tem lahko preberete $v$ Merilih za akreditacijo visokošolskih zavodov in študijskih programov (Svet Republike Slovenije za visoko šolstvo, 2004 b). 